\title{
Las artes de un predicador en guerra con las Luces: teoría y práctica de la oratoria sacra según el epistolario de Fray Diego José de Cádiz
}

\author{
Fernando DURÁN LÓPEZ \\ Universidad de Cádiz \\ fernando.duran@uca.es
}

\section{RESUMEN}

A finales del siglo XVIII el predicador itinerante más famoso de España fue el capuchino Fray Diego José de Cádiz, perfecto representante del tipo de oratoria sagrada realizada en las denominadas «misiones populares». Este artículo estudia las características del modelo retórico aplicado por el autor por medio de la correspondencia que mantuvo con su director espiritual, Fray Francisco Javier González, en la que puede apreciarse las implicaciones y el sentido de la teoría y la práctica de la oratoria religiosa del momento.

Palabras clave: Oratoria sagrada, reforma de la predicación, espiritualidad del siglo XVIII, Fray Diego José de Cádiz.

\begin{abstract}
At the end of the eighteenth-century, the most famous travelling preacher in Spain was the capuchin Fray Diego José de Cádiz, a perfect instance of the kind of sacred oratory developed in the so-called «popular missions». This paper studies his rhetorical model of preaching as seen through the correspondence with his spiritual director, Fray Francisco Javier González; in these letters we can find out the implications and whole sense of the theory and practice of contemporary religious oratory.

Key words: Sacred oratory, reform of preaching, eighteenth-century spirituality, Fray Diego José de Cádiz.
\end{abstract}

\section{Siglo de las luces, siglo tenebroso}

El tema que voy a abordar atañe a un segmento de la religiosidad no ilustrada, que sigue siendo con mucho la mayoritaria en la España de fines del siglo XVIII: la predicación, concretamente la que formaba parte de las misiones interiores y que 
constituyó una de las vías por las que el clero reaccionario desempeñó su campaña contra la Ilustración.

En el siglo XVIII existe una lucha entre Ilustración y Fe. No quiero decir desde luego que los ilustrados careciesen de creencias religiosas, ni que una cosa y la otra fueran incompatibles, sino que, en su esencia misma, la mentalidad ilustrada implica desplazar la fe al ámbito privado, racionalizarla y colocarla en un plano secundario y subordinado a otros órdenes de la estructura social y estatal. De ahí que la cultura religiosa en general no se considere un objeto habitual de atención al hablar de las Luces, salvo para ver cómo la Iglesia y la fe tradicionales se resistieron a los cambios, y cuáles fueron las estrategias, los conflictos o las renuencias de los ilustrados a la hora de reajustar el catolicismo español al nuevo orden al que aspiraban, que seguía siendo a pesar de todo un orden cristiano y católico.

Menos aún se estudia la anti-Ilustración. Esto es fácil de entender, si no de disculpar, cuando se constata que, en los modelos evolutivos sobre los que se construyen las disciplinas académicas, los anti suelen resultar siempre postergados. La historia de la cultura se hace sobre las afirmaciones, no sobre las negaciones, pero podemos preguntarnos si eso responde a la realidad histórica, donde en casi cada época son muchos más quienes niegan que quienes afirman, los que repiten que los que innovan. Valga esto para dejar claro que seguramente en la España de finales del XVIII el tono general de la nación estaría más cerca de los individuos que voy a presentar aquí, que de escritores como Cadalso, Meléndez Valdés, Jovellanos o Quintana, por citar ejemplos emblemáticos. Claro que en el curso de la civilización calidad y cantidad, valor y peso, no acostumbran a ir aparejados. Por eso mismo es importante asumir, en contra del natural prejuicio, que el pensamiento ultraconservador $-\mathrm{o}$, mejor, reaccionario, en el sentido de que no es una mera actitud defensiva, sino ofensiva-, no por llevar implícita la voluntad de conservar lo existente o de volver a un estado de cosas propio de un cercano pasado ha de entenderse que esté carente de fuerza creadora, de capacidad de innovar; a veces son solo cambios sutiles, pero a menudo también si parece tan mimético es justo porque nadie se toma la molestia de estudiarlo.

La batalla entre reformadores y reaccionarios —omitiendo a este fin la amplia diversificación que va implícita en ambos términos - se mantiene más o menos larvada durante la mayor parte del XVIII, pero cada vez más enconada hasta la ruptura violenta que, como sabemos, se producirá a partir de 1808, y sobre todo, de 1814. En las últimas décadas del siglo se viven continuos afloramientos conflictivos, especialmente como rebote de los sucesos de Francia, y en particular durante la guerra contra la República Francesa en 1793-1795, que dio lugar a una vasta lucha ideológica, no solo contra las ideas revolucionarias venidas del país vecino, sino contra el jansenismo y el regalismo que habían crecido entre el clero y el gobierno español al amparo de diferentes ministerios borbónicos. Pero ya antes se habían producido campañas menos notorias, a pie de calle y de iglesia, en el ámbito 
de la predicación. En la esfera del control directo de los sentimientos religiosos del pueblo, los reaccionarios siempre tuvieron la iniciativa, porque dominaban los púlpitos. Y al respecto cabe recordar que la escisión entre ilustrados y reaccionarios refleja también, en buena medida, una ruptura cultural entre las élites y el pueblo, entre la cultura letrada y la popular. Los ilustrados actúan en círculos elitistas de sociabilidad, de enseñanza, de transmisión impresa de la cultura, con desprecio por las masas iletradas, pero esas masas iletradas permanecen atadas al universo reaccionario a través de otras fórmulas de devoción, de arte, de discursos y de transmisión de ideas, que dominan un amplio espectro de la vida cotidiana, casi sin oposición ni alternativa alguna.

De esas fórmulas, una de las más exitosas es la de la predicación, que es mucho más que la sátira grotesca y literariamente depauperada que muestra el Fray Gerundio. Los sermones impresos que se conservan, decantado fruto del estudio y de un esmerado formalismo, solían ser las solemnes oraciones pronunciadas con motivo de algún acto ceremonial, efeméride o funeral, y por su propio auditorio y naturaleza representan un testimonio alejado de la predicación oral ante el pueblo. ${ }^{1}$ Por otra parte, tenemos unos sermones más abundantes y populares, pero que rara vez pasan por las prensas, que corresponden a una predicación espontánea y directa, lo cual no implica que, como veremos, no fueran igualmente resultado de una reflexión sobre el arte oratorio y sus recursos emocionales, articulados mediante una técnica muy elaborada. La manifestación más plena de esa oratoria sacra es la que constituía el ingrediente principal de las misiones de evangelización habituales en la Contrarreforma, y que, por poseer una fisonomía diferenciada de las destinadas a esparcir la fe católica entre infieles o pueblos paganos, reciben a menudo el nombre de misiones interiores o misiones populares. ${ }^{2}$

\footnotetext{
${ }^{1}$ Sobre esos sermones impresos véase una certera aproximación en F. Aguilar Piñal (1989).

2 En general, todas las obras que tratan la oratoria sacra y las relaciones de religión y sociedad se ocupan, casi siempre rutinaria y repetitivamente, de las misiones. En cambio, la bibliografía específica es escasa si la comparamos con la importancia y persistencia del fenómeno, y suele centrarse en la práctica de los jesuitas anterior a 1767: esta culmina en su vertiente práctica y teórica con el $\mathrm{P}$. Pedro Calatayud, quien escribió un célebre y muy editado manual para predicadores misionales. Una descripción de cómo eran las misiones en el XVII puede verse en A. Domínguez Ortiz (1973), pp. 389-392, F. Sánchez Blanco (1988), M. Morán y J. Andrés-Gallego (1992), pp. 193-198, F. Herrero (1996-2004 y 2003) y S. Gómez Navarro (2008). Durante el siglo siguiente, su fisonomía no era muy distinta, aunque progresivamente sí lo fue siendo el contexto sociocultural del país. Véanse los trabajos de W. Callahan (1989), pp. 68-70, J. Berrueza (1998) y, sobre todo, F. L. Rico Callado (2002 a 2003). Los estudios de este último autor son con mucho los más importantes y completos que se han realizado sobre la materia en España, y giran sobre la predicación jesuita de la primera mitad del siglo. La guerra de 1808 y la traumática instauración del régimen liberal, con la exclaustración de regulares y la desamortización, justificaron una profunda decadencia de la práctica misionera en la primera mitad del XIX, pero esta resurgió con
} 
Las misiones eran pieza fundamental de la propaganda y el refuerzo doctrinal en el territorio diocesano, sobre todo en los ámbitos rurales apartados de las sedes episcopales. Domínguez Ortiz las califica como «uno de los grandes hechos sociales del siglo XVII, el máximo esfuerzo hecho a escala nacional para trasmutar el ideal caballeresco en el ascético». ${ }^{3}$ Aunque presentan una tipología muy amplia según el momento y sus actores, pueden reducirse a un esquema común: un pequeño grupo de sacerdotes, a menudo dos y casi siempre regulares, acudía varios días a una localidad, dentro de una ruta previamente establecida en determinada diócesis. Allí llevaban a cabo un acelerado programa de activismo espiritual cuyo centro inexcusable eran varios vibrantes sermones, pero que iban acompañados de procesiones, confesiones y comuniones masivas, mortificación de la carne mediante ayunos o disciplinas, elucidaciones de la doctrina a escolares e iletrados, actos de devoción a los santos o vírgenes de culto local, reuniones con autoridades, párrocos y fuerzas vivas. Durante esos días los misioneros instigaban denodadamente un estado de emergencia espiritual y moralidad extrema, arreglando las desavenencias entre vecinos, casando a las parejas amancebadas, cerrando teatros y lugares de vicio, convirtiendo o reconviniendo a notorios impíos... ${ }^{4}$ Las implicaciones sociales, culturales e ideológicas de estas campañas son tan amplias y relevantes como se deja suponer, pero me interesaré solo por el instrumento de que se valían y, por tanto, por ese peculiar género literario y uso específico del lenguaje que conforma la oratoria.

fuerza en la segunda, con el nuevo y pujante activismo religioso del momento, en el que destacó Antonio María Claret; una visión ajustada de cómo eran en ese periodo las misiones en Andalucía, en W. Callahan (1989), pp. 230-233, E. de Mateo Avilés (1989), y abarcando un periodo posterior y nuevas transformaciones del procedimiento pastoral, Ruiz Sánchez (1998).

${ }^{3}$ A. Domínguez Ortiz (1973), p. 389.

${ }^{4}$ F. L. Rico Callado ha denominado esto «la propuesta de un "modelo devoto" dirigido a grupos sociales amplios» (2003, p. 111), es decir, un programa de transformación gradual de la vida cotidiana ajustado al tejido social sobre el que se operaba, erradicando o transformando ritos, símbolos, difundiendo la catequesis, la confesión y las lecturas pías, insistiendo en la pacificación de rencillas, la salvaguarda del orden familiar y la obediencia a las autoridades en el interior de las comunidades, implicando a las jerarquías locales en el afianzamiento de los logros espirituales obtenidos, regulando el tiempo libre y purificando la conducta sexual y las costumbres mediante una aguda conciencia del pecado que abarcase todo momento y espacio... Para desarrollar tal agenda cobraron notable importancia las misiones penitenciales, en las «que destacaron los elementos espectaculares y afectivos, así como una acción pastoral desarrollada en un corto de espacio de tiempo, [...] en claro contraste con la misión catequética, que hacía un mayor hincapié en la formación de los fieles y en la que, por tanto, los componentes pedagógicos gozaban de un mayor peso», Rico Callado (2003), p. 112. 
La predicación misional genera un modelo retórico diferente al de los solemnes sermones que se predicaban en la corte, en las ceremonias urbanas o para publicarse. Domínguez Ortiz explica esa «disonancia aguda» como la que va entre «el estilo alambicado, preciosista, más adecuado al lucimiento del orador que a la edificación de los fieles», de "vacua retórica e intelectualismo que nada decía al corazón», que caracterizaría la oratoria barroca del XVII —el estilo de los Fray Hortensio Paravicino y similares-, y «el movimiento misional, rudo, popular, sin galas ni ornatos retóricos», «accesible a la gran masa de los oyentes». ${ }^{5}$ En realidad, se trata de un aparato distinto de recursos y de ornatos, no de su ausencia, pero en efecto la oposición se sostiene en dichos términos. Por su carácter pegado al terreno, el éxito de las misiones pende directamente de una figura carismática: la del misionero, un predicador itinerante perteneciente a alguna orden religiosa, tarea muy en particular reservada en los siglos XVII y XVIII a jesuitas y capuchinos. Estos últimos, de una tradición devocional harto más popular y menos intelectual que los padres de la Compañía, y con amplio terreno libre tras la expulsión en 1767 de aquellos, destacaron por su atención a este ministerio y por su extrema ideología reaccionaria. Como recuerda Melgares Raya, las constituciones de la orden capuchina prescribían el deber esencial de misionar a sus religiosos y establecían, además, una forma de predicar según el ejemplo de San Francisco: una exposición lineal de vicios y virtudes, que evitase el lenguaje «demasiadamente cortado, afectado y compuesto, como no conveniente al desnudo y humilde del Crucificado, usando de palabras desnudas, simples y humildes, pero inflamadas, divinas y llenas del Amor de Dios». ${ }^{6}$ Así pues, vocacionalmente, los capuchinos practicaban una oratoria que presumía tanto de directa como de inflamada. A tal fin, los misioneros han de estar dotados de una intensa vocación proselitista y de un ardor y celo formidables; tienen que saber percibir y dominar las reacciones de la gente, los resortes del miedo, la sorpresa, el arrepentimiento...

El personaje del que me ocupo en estas páginas fue un completo dechado de predicador misional capuchino. Domínguez Ortiz, siguiendo una lectura generalmente repetida, sostiene que, en las misiones, «el XVIII, aunque de gran actividad, no pertenece ya a la época creadora; los métodos (las industrias) estaban hallados, y solo quedaba aplicarlos, en ocasiones mecánicamente y dejándose llevar por una creciente rutina». ${ }^{7} \mathrm{Y}$ el mismo autor insiste en que «los años áureos de las misiones corresponden al siglo XVII y primera mitad del XVIII, con algunos epígonos, de los que el más notable fue Fr. Diego José de Cádiz», ${ }^{8}$ mientras que López-Cordón asegura que las misiones en el XVIII mantienen «fórmulas y hábitos

\footnotetext{
${ }^{5}$ A. Domínguez Ortiz (1973), p. 389.

${ }^{6}$ Constituciones de la orden, editadas en 1644 y citadas por J. Melgares Raya (1995), p. 1034.

${ }^{7}$ A. Domínguez Ortiz (1973), p. 390.

${ }^{8}$ A. Domínguez Ortiz (1979), p. 13.
} 
procedentes de la centuria anterior, que apenas evolucionaron». ${ }^{9}$ En este juicio generalizado influye que casi todo el repertorio teórico y sistemático de la práctica misionera lo codificaran autores tempranos, de los que uno de los más tardíos es en 1754 el P. Calatayud: Misiones y sermones... Arte y método con que las establece, las cuales ofrece al público en dos tomos para mayor facilidad y expedición de los ministros evangélicos, párrocos y predicadores en misionar, doctrinar $y$ predicar... ${ }^{10}$

Pero esto bien podría ser, al menos en parte, un efecto óptico del hecho que ya he señalado: la perezosa desconsideración que acostumbra a acompañar las formas de la vida religiosa contrarreformista cuando se abordan en el siglo ilustrado. Convengo más bien en este punto con Sánchez Blanco cuando afirma, hablando de la ideología de Pedro Calatayud que: «aun admitiendo que en este género literario la exageración es un instrumento natural» - igual que lo es la repetición de temas y recursos tradicionales, añado yo-, «también hemos de admitir que, cuando de pronto en la predicación se cambia el objeto de la crítica y son otros los vicios contra los que clama el predicador, es razonable suponer que esto no se debe exclusivamente a un capricho de este, sino que se da una presión ambiental que obliga a este cambio temático»». ${ }^{11}$ Hay una cantidad de cambios, a veces muy sutiles y otras mucho más evidentes, que manifiestan una adaptación al presente, a nuevas inquietudes y diferentes adversarios. En cualquier caso, mi propósito es modesto y, sin detenerme a establecer líneas de continuidad o ruptura entre la oratoria misional de fines del XVIII y periodos anteriores, presentaré algunos aspectos del caso del P. Cádiz, no sin advertir, con Rico Callado, que la ausencia de estudios generales no permite indagar sobre toda la extensión y variedad del fenómeno misional, pero los estudios regionales o parciales dejan ver que era más diversificado de lo que suele asumirse: «las misiones no fueron una realidad uniforme, ni tanto desde un punto de vista institucional ni "metodológico" [...]. La misión "modelo" corresponde, en cierta medida, más a una construcción del historiador que a una realidad histórica». ${ }^{12}$ Esto es lo que hace interesante el planteamiento de un caso eminente,

\footnotetext{
${ }^{9}$ M. V. López-Cordón (1978), p. 72.

${ }^{10}$ Entre los anteriores puede destacarse otra obra jesuítica: Martín de Lanaja, El misionero perfecto deducido de la vida, virtudes, predicación y misiones del venerable y apostólico predicador P. Jerónimo López, de la Compañia de Jesús. Con una práctica muy cumplida de la perfecta forma de hacer misiones con fruto de las almas, conforme al estilo que en ellas guardaba el mismo V. P. y otros misioneros insignes (Zaragoza, 1678).

${ }^{11}$ F. Sánchez Blanco (1988), p. 16. Este autor ofrece una inteligente revisión del modo como Pedro Calatayud y otros jesuitas de su tiempo introducen cambios en su discurso y en sus prácticas devocionales expresamente encaminadas a adaptarlas como un instrumento antiilustrado.

${ }^{12}$ F. L. Rico Callado (2002, «Conversión...»), p. 365.
} 
que resultará en parte representativo de una práctica generalizada y en parte irreductiblemente individual. Vayamos, pues, al caso.

\section{Fray Diego José de Cádiz: capuchino, misionero y santo}

Sobre la señera figura de Fray Diego apenas hay estudios que no sean hagiográficos y apologéticos, y que por lo tanto faciliten una aproximación rigurosa, documentada y no confesional a su personalidad y obra. Pero son suficientes para trazar un bosquejo fiable. ${ }^{13}$ Nació en Cádiz en 1743, hijo de un militar gallego que trabajaba al servicio de los Duques de Arcos. Se decidió por la vida religiosa cuando tan solo tenía catorce años, venciendo — según cuenta- la oposición de su familia. En 1757 ingresa en el noviciado de los capuchinos, y profesa en 1759. En 1766 se ordena sacerdote en Carmona y evita ser destinado a la enseñanza, pues se sentía llamado a una vida más activa. Tras varios años en el convento de Ubrique, empezó a predicar y pronto inició su tarea misionera. En 1774 comienza su trato con Fray Francisco Javier González, religioso de la Orden de Mínimos de San Francisco de Paula, que pronto se convertiría en su director espiritual y la persona que más profunda huella imprimió sobre su conciencia. Sus giras de predicación se hacen cada vez más amplias y le conducen a poblaciones de mayor importancia. En 1783 predica ante miembros de la Familia Real en Aranjuez. $\mathrm{Al}$ año siguiente, muere el P. González y su nuevo director, el clérigo granadino Juan José Alcover e Higueras, le asistirá hasta la muerte, a pesar de que no obtuvo nunca de él la complicidad de que gozó con su predecesor. En 1789 la Revolución Francesa le radicaliza en sus posturas ultramontanas y los choques con el poder civil se hacen más frecuentes. Durante la guerra con la Convención, en 1794, publica su obra doctrinal más ambiciosa, El soldado católico en guerra de religión. Carta instructiva ascético-histórica-política en que se propone a un soldado católico la necesidad de prepararse, el modo con que lo ha de hacer y con que debe manejarse en la actual guerra contra el impio partido de la infiel, sediciosa y

${ }^{13}$ La más completa y mejor fuente sigue siendo el largo artículo de M. V. López-Cordón (1978), que ha de tomarse como primera referencia, en tanto que las abundantes biografías escritas en el XIX y el XX son puramente hagiográficas. Sobre esas biografías, sus fuentes primarias y el punto clave de la relación del P. Cádiz con sus dos confesores, véase F. Durán López (2003), cap. III, donde también se incluyen las cortas autobiografías del fraile, escritas por mandato. Una exhaustiva recensión bibliográfica puede verse en S. Ausejo (1947), además de en las fuentes generales (la Bibliografía... de Aguilar Piñal). Los estudios sobre el pensamiento reaccionario y sobre las consecuencias de la revolución francesa en España hacen siempre referencia a El soldado católico en guerra de religión. En la bibliografía solo recojo algún que otro estudio de los varios que hay sobre aspectos concretos, como sus campañas contra el teatro y los espectáculos públicos, su conflicto con Lorenzo Normante y la polémica en torno al lujo, algunas misiones en determinadas localidades, etc., sin agotar todas las referencias posibles, que siguen pecando de dispersión. 
regicida Asamblea francesa. En 1794-1795 recorre en una larga gira de predicación Galicia, Asturias, León, Zamora y Salamanca. Pasa el resto de sus años en Andalucía y muere en Ronda, víctima de la fiebre amarilla, el 24 de mayo de 1801.

Fray Diego ofrece el cuadro completo del clérigo reaccionario que nunca hace la menor concesión en el rigorismo de sus creencias morales y religiosas. Se negó a aprender francés por no tener contacto con los libros que se publicaban en esa lengua y era proverbial su capacidad de citar de memoria la Biblia, en concreto el Antiguo Testamento, de cuya validez doctrinal fue decidido defensor. Se destacó asimismo por sus ataques al teatro, los bailes, las corridas de toros y cualquier diversión pública, sosteniendo la tesis de que se incurría en pecado mortal solo por asistir. Al mismo tiempo, su defensa de los derechos, rentas y preeminencia de las autoridades eclesiales sobre las civiles le ubica en una a duras penas disimulada oposición a los programas reformistas y regalistas de los gobiernos borbónicos, por lo que padeció un buen número de encontronazos con los poderes episcopales y civiles, ${ }^{14}$ aunque estos nunca fueron demasiado severos con él. En 1784 fue acusado ante el Consejo de Castilla de haber atacado en un sermón los derechos regios sobre ciertas rentas eclesiásticas; de resultas, lo desterraron brevemente a Málaga. En 1786, en Zaragoza, fue él quien denunció a la Inquisición al catedrático de la Sociedad Económica, Lorenzo Normante, por proposiciones de economía política contrarias a la doctrina cristiana (la utilidad del lujo y del préstamo con interés, los males derivados para la sociedad del celibato sacerdotal y del excesivo número de sacerdotes); Normante, a su vez, lo acusó ante el Consejo de Castilla por combatir las regalías en un sermón. El Consejo emitió un duro dictamen contra Fray Diego.

En otras ocasiones, el P. Cádiz tuvo sus problemas con la Inquisición misma, que él tanto defendía, por fomentar devociones supersticiosas. En 1791 un capuchino de Sevilla denunció al Santo Oficio unas hojas impresas en que se veía a Jesucristo, la Santísima Trinidad y Fray Diego, junto con versos que aludían a maldiciones y males de ojo curados por la intercesión de este. En 1796 un párroco de Cuenca lo denuncia por un trisagio que el predicador hacía circular y que debía rezarse diariamente para librar al creyente de todo mal. En 1799 se denunció el romance Noticia del milagro que ha obrado la Santa Cruz de Caravaca, donde se relacionaba ese presunto milagro, que la Iglesia consideraba falso, con cierto modo de persignarse que enseñaba el P. Cádiz. En los tres casos el Tribunal entendió los papeles como heterodoxos y ordenó que se recogieran. Otras veces fue amonestado por su excesivo uso de las indulgencias y por sus «cedulitas» de la Virgen y los santos (unos papelitos donde el fraile escribía frases como «Ave María Purísima» y que el enfermo debía tragarse, previa limosna). Las devociones milagreras del $\mathrm{P}$.

\footnotetext{
14 Recuerda Sánchez Blanco que «los misioneros no hacían gala de discreción en sus métodos $\mathrm{y}$, para conseguir sus propósitos, se pasaban por alto lo que pensaran las autoridades civiles y eclesiásticas» (1988), p. 16.
} 
Cádiz, pues, chocaban con un aparato eclesial ya mucho más sobrio e intelectual en tales terrenos. No obstante, se guardaba la apariencia de que el proceso no se seguía contra él, sino contra desviaciones de su fama de las que no era responsable. Eso resultaba también conveniente para no menoscabar la reputación de un predicador tan celebrado.

\section{Predicación y lucha contra las Luces}

Estos choques enumerados con la autoridad muestran la justa dimensión del personaje: un activista que concebía el conjunto de su vida como una sostenida campaña política contra la Ilustración, un recio adversario del progreso, un integrista y un nostálgico de las hogueras inquisitoriales. Al lado, íntimamente trabada, está su fama como predicador que anda en boca de todos, amigos y enemigos, y que lo convirtió en una figura emblemática. Alguien con una reputación espiritual tan extendida era difícil de soslayar en un país clericalizado donde la práctica pública de la religión acaparaba la mayor parte del espacio y tiempo colectivos. No era una figura a quien fuera sencillo criticar o despreciar. Incluso sus rivales ideológicos y los afines que no comulgaban con su estilo de predicar hablan de él con acentos de admiración y respeto, nunca con desprecio, como constata el recuerdo que proyecta el liberal José Joaquín de Mora en aquellas octavas que empiezan «Yo vi aquel fervoroso capuchino / timbre de Cádiz, que con voz sonora, / al blasfemo, al ladrón, al asesino / fulminaba sentencia aterradora...». ${ }^{15}$

Mas la lectura del buen puñado de sermones impresos que dejó tras su muerte no hace justicia a celebridad tan ponderada. ${ }^{16}$ Ya ha quedado dicho que la predicación misional era un arte oral, cuyas trazas no resultaban trasladables a los sermones de ceremonia, que eran los que luego venían a dar en las imprentas. Hay, sin embargo, fuentes indirectas que permiten reconstruir algunas claves de su técnica oratoria y, a la vez, del modo como esa técnica era elaborada y sus efectos digeridos. Para ello, podemos acudir a la correspondencia mantenida con su director de conciencia, Fray Francisco Javier González, quien le asistió durante un decenio, entre 1774-1784. En la dirección espiritual, cuando hay una aguda compenetración entre maestro y pupilo, como es el caso, podemos hablar casi de una sola identidad, una mente expresada a dos voces, y de una virtual coautoría en las obras que resultan del trato. El director vivía de asiento en Sevilla y era él mismo un reputado predicador, aunque de formación más intelectual y praxis más ceremonial que la que moldeaba

\footnotetext{
15 Dedica dos octavas enteras a Fray Diego en la sección VIII de su «Fragmento de un poema», incluido en su volumen de Poesías de 1853.

${ }^{16}$ Véase por ejemplo, sin agotar la materia, la Colección de las obras del R. P. Fr. Diego José de Cádiz, misionero apostólico del orden de menores capuchinos de N.S. P. S. Francisco de la provincia de Andalucía, que recopiló en cinco volúmenes, en 1796, lo más granado de su producción oratoria. En las fuentes citadas en una nota anterior se puede localizar el detalle de su producción impresa en los diferentes géneros en que se prodigó.
} 
a los misioneros capuchinos. Como Fray Diego vivía entre conventos de su orden y frecuentes giras misionales, la tutela de su conciencia se desempeñaba mediante cartas y eso nos ha permitido conservar el intercambio. ${ }^{17}$ Dado que el ministerio escogido por el pupilo era el de la predicación, es asimismo uno de los asuntos centrales de las consultas evacuadas con su director, que incluyen la preparación de los sermones, reflexiones sobre sus métodos, resultas, alcances morales y espirituales...

Cuando Fray Diego entró en contacto con quien iba a ser su guía, ya gozaba de celebridad como misionero. Su director no decidió que así fuera, pero tuvo un papel relevante en reforzar y orientar tal compromiso, grabando a fuego en el capuchino la convicción de que su destino era salvar a España de la corrupción del siglo filosófico a golpe de sermones; de que estaba predestinado a ser, como le susurraban tempranas visiones, capuchino, misionero y santo. En una ocasión le escribió: «Dios quiere servirse de ti ignorantísimo, y te ha traído a la religión y al ministerio, para que, armado de su omnipotencia, sabiduría y virtud, declares la guerra al dominante libertinaje y obscurantísima ilustración del siglo tenebroso» (FFJG a FDC, 26-VI-78, p. 125). Pasajes de este jaez podrían multiplicarse sin esfuerzo. No en vano el único elemento sustancial de renovación respecto al siglo anterior que María Victoria López-Cordón reconoce a las misiones en tiempos del P. Cádiz era la necesidad de instrumentalizarlas como cauce «para la propagación y defensa de unos idearios poco compatibles con los que desde el poder se intentaban ir imponiendo»». ${ }^{18}$ Ya no es mera evangelización interior: es activismo antiilustrado y militancia reaccionaria. Así pues, Fray Francisco Javier tenía muy claro que Fray Diego había de alzarse como instrumento divino para erradicar la Ilustración del siglo y restituir los poderes y privilegios de la Iglesia, que religiosos como ellos creían decaídos y amenazados en España. ${ }^{19}$

${ }^{17}$ Se trata, sin embargo, de ediciones de naturaleza hagiográfica de principios del XX, cuya fiabilidad textual y rigor filológico no se pueden garantizar. Todas las citas del epistolario entre Fray Diego y Fray Francisco Javier González, publicado con el título de El director perfecto y el dirigido santo, se indican en el cuerpo del texto con las siglas de emisor y destinatario, fecha y página en la edición manejada: A. de Valencina (1924).

${ }_{18}^{18}$ M. V. López-Cordón (1978), p. 73.

19 Aunque tenía algún conocimiento del pensamiento reaccionario de su tiempo (el P. Ceballos, por ejemplo), su ignorancia de los autores modernos, su fijación con el Antiguo Testamento y la Patrística y su insistencia en subordinar el poder civil a la Iglesia, hacen de él, en sentido estricto, «más un tradicionalista a ultranza [...] que un reaccionario al nuevo estilo», «a pesar del papel que jugó en el inicio de la praxis de la ofensiva contrarrevolucionaria», López-Cordón (1978), p. 82. Bien es verdad que si, como aquella estudiosa reconoce, la importancia del personaje radica más en la praxis que en la teoría, la diferencia entre ambas categorías ideológicas se difumina: a efectos prácticos es un activista de la reacción. W. Callahan resume esa capital cualidad política de las misiones en el XVIII: «al considerar el mundo material como un mundo corrupto, los misioneros rechazaban 
Con objeto de realizar dicha obra, la Providencia Divina había inspirado al capuchino para predicar a las gentes. Existe una importante carta escrita al final de su carrera a un religioso catalán que versa sobre el «don o gracia de predicación» y su idea de la oratoria sagrada. El capuchino quiere dejar claro que su destreza en el púlpito no es fruto del estudio o la capacidad intelectual, sino el regalo de la Providencia a un humilde hombre casi iletrado. La prueba de ello, asegura, es que «ignoro enteramente las reglas de la oratoria y el modo de formar según ellas un sermón». Dice haber estudiado de joven tales reglas, pero que Dios le negó entendimiento y provecho en sus lecciones y nunca pudo acabarlas, por más que volvió a intentarlo en años sucesivos. No obstante, en seguida afirma que en sus primicias como orador sacro empleaba el método «de proponer en los sermones un asunto útil, probar o convencer su verdad, y persuadir a la voluntad a excitarla a que la observe, etc.», mas que luego, por su incapacidad de entender los sermones impresos, en especial los franceses, dejó ese sistema basado en el raciocinio en favor de otro imitado de San Bernardino de Sena. Era un método más improvisado:

\begin{abstract}
antes de predicar no acierto a formar un sermón. Estudio cuanto puedo, revuelvo libros, singularmente Santos Padres y expositores; mas si me dedico algunos días a prevenir el sermón, gasto inútilmente el tiempo, hasta que el mismo día, o cuando más el anterior, va ocurriendo el modo y el rumbo que ha de tener, según las especies que he visto o me ocurren para el asunto. Son muchos los casos en que he subido al púlpito con la angustia imponderable de no haber podido formar ni menos vestir la idea en sermones de empeño y de materias intrincadas; pero poniendo mi corazón con humilde resignación en la voluntad de Dios, y pidiéndole concederme que trate yo su divina palabra con la dignidad, honor y respeto (si es posible) con la que trataba su Unigénito, Nuestro Redentor, siempre he visto como de bulto su soberana asistencia y el Ego dabo vobis os et sapientiam, etc.
\end{abstract}

El resto de la carta es una retahíla de protestas de humildad y de que nada sale de su boca que sea mérito propio, sino favor que Dios le otorga, hasta concluir que «soy naturalmente muy escaso de discurso y de formar conceptos, ideas, etc. en toda especie de asuntos [...]. Solo en el púlpito no se advierte este natural defecto»». ${ }^{20}$ Así pues, bajo la humillación ritual, late un concepto oratorio basado en la

esencialmente el papel secular asignado a la Iglesia por la monarquía borbónica», (1989), p. 70.

${ }^{20}$ Todas estas citas son de la carta de Fray Diego al P. Jaime de Puigcerdá, fechada en Ronda a 30-VIII-1793. Había sido impresa en la biografía del gaditano escrita por Sebastián de Ubrique en 1926, pero cito por la edición moderna a partir del original autógrafo conservado en el archivo de los capuchinos catalanes: en E. Zaragoza Pascual (2003), pp. $238-241$. 
improvisación y que rechaza un previo ensamblaje racional del argumento en beneficio de un carisma emocional y espontáneo.

Su noción de la retórica, pues, se basa en esas notas: reforzar la vocación pastoral, el mandato providencial y la lucha contra las Luces, así como la búsqueda de un estilo improvisado y el rechazo de la predicación estudiada e intelectual. Eso no quiere decir que no exista un razonamiento teórico y una elaboración de la técnica: para entender cómo se va modelando ese estilo oratorio, la mejor fuente es esta correspondencia con su director, que tuvo un papel central en que tales características fuesen aceptadas y desarrolladas por el capuchino. ${ }^{21}$

\section{Teoría práctica de la predicación misional}

Lo primero es preparar el espíritu. La eficacia del misionero exigía que, antes de cada misión, se refugiase en un retiro de meditación, que le pusiese en estado propicio para completar con fruto su tarea. El P. González insuflaba en su discípulo una excitación carismática para sus sermones y, a tal fin, al prepararlos le imponía intensa oración, antes que estudio. Quería que afrontase su empeño imbuido de un estado emocional, el mismo que se pretendía inducir en sus oyentes. Fray Diego, en cambio, a quien atemorizaban sus ardientes impulsos, tendía a refrenarlos con el estudio frío y calculado, elaborando intelectualmente sus prédicas, y le costaba concentrarse en la oración y obtener de ella la emoción necesaria. Así se lo explicaba en 1777:

Para esta Misión [de Cádiz] trabajé más en estudiar que en orar: no sé si faltaría al precepto de usted. Yo no lo olvidaba; pero era poco lo que hacía de oración, porque una interior zozobra, o no sé qué, me obligaba al estudio. En él hallé algo de facilidad, y me parece que oportuno. En el púlpito me hallaba sin susto, temor, ni cobardía; hablaba al clero con mucho modo y veneración, pero con más que mediano ardor y actividad. [...] Me parece no veía los mejores semblantes, aunque después me aseguran el fruto (FDC a FFJG, 22-VII-77, pp. 53-54).

Fray Diego no tiene miedo en el púlpito precisamente porque por medio del estudio controla la situación y se resguarda de reacciones imprevisibles, pero al mismo tiempo esa moderación y frialdad no parece ser la que más impacto obtenga en el auditorio. González iba a empujarle decididamente a entregarse a su carisma, a abandonarse a una predicación irracionalista, en la que iba a tener que enfrentarse con sus miedos y vencerlos con espíritu audaz. Veamos la misión predicada en Écija. En la primera carta que envía desde allí a su director, explica que padeció grandes aprietos para concentrarse en los sermones y hallar asuntos predicables acomodados a un público en el que tropezaba con resistencia. La materia del primer ${ }^{21}$ No es la única correspondencia de Fray Diego que se ha editado, pero sí es la más
interesante a estos respectos, y a ella voy a limitarme. 
sermón solo se le vino a la mente una hora antes de pronunciarlo. Al regresar de él, cuando se despojaba de las vestiduras:

se me ocurrió en el pensamiento: ¿No me das las gracias? ¿No lo he hecho bien? Púseme de rodillas y di brevemente al Señor las gracias. Estas ocurrencias no salen de la esfera de un natural recuerdo: nada oigo, ni entiendo, sobrenatural; mas con la experiencia, y más por las instrucciones de usted, creo firmemente es Dios el que lo dice, y así lo recibo y agradezco (FDC a FFJG, 14-XI-75, pp. 156157).

El fraile siempre distingue con claridad los fenómenos abiertamente milagrosos y sobrenaturales, de las voces y visiones interiores que le asaltan en el pensamiento o la fantasía, las cuales sin embargo también se atribuyen a intervención divina. El conflicto que se plantea en esa misión de Écija, como bien vio el P. González, es el del miedo al fracaso, el no percibir en el auditorio la reacción o la predisposición necesaria para obtener el fruto, que no es otro que una rápida y catártica conversión religiosa. La oratoria sacra establece una comunicación estrecha entre orador y público, y las reacciones de este son algo que Fray Diego reseña siempre como algo esencial. ¿Pero y si la frialdad de los fieles se contagia al predicador? ¿Y si no consigue encontrar el resorte que convulsione las conciencias de los oyentes? Uno de los esfuerzos más continuados de su guía espiritual se encamina a extirpar el miedo al fracaso, que reputa efecto del amor propio. Así le responde: «Síguese que tu temor era efecto de tu propio amor, que, como vanísimo que es, sentía exponerse por la primera vez al público de una ciudad, sin propia prevención y estudio para captar la estimación, y hacerse lugar en su aprecio» (FFJG a FDC, 18-XI-75, p. 160). Le recuerda que, como prueban las voces que había oído tras el primer sermón, el predicador solo es un instrumento de Dios y ha de abandonarse a su voluntad, que le concederá el éxito o el fracaso. Si se ve como un intermediario, podrá eliminar la vanidad del triunfo - que no le pertenece-y, si elimina la vanidad, se esfumará de igual modo el miedo a fracasar.

\footnotetext{
Desengáñate, Fray Diego; por más que te esfuerces, nada puedes, ni debes esperar poder, sin que se te dé. Predicas desabrido, duro, seco, porque no ves conmovido el público que quisieras convertir, porque te parece que amas su bien. Sí, lo amas; pero esa dureza en los sermones, ese desconsuelo por lo que ves, ese conturbarte porque nada se adelanta, $[. .$.$] te convence de que no hay en ti pureza de intención,$ y rendimiento de entendimiento y voluntad a los juicios y voluntad de Dios (FFJG a FDC, 18-XI-75, pp. 161-162).
}

Puede parecer extraño cuando se conocen los abundantísimos testimonios que subrayan la facundia y el ardor del P. Cádiz en el púlpito, su facilidad para predicar, su destreza para alterar las emociones de los oyentes, pero él se consideraba - y no cabe atribuirlo solo a convencional humildad - un orador árido que había de 
arrancarse cada palabra con esfuerzo, doblegando sus temores. En 1779 escribía a su director:

Debo añadir que mi predicación siempre o casi siempre es con angustia y fatiga interior, que no hay sermón, ni plática, ni conversación que en tono de ella haya de tener, que no sea con mil angustias y costándome gotas de sangre como del corazón el hacerlo, y aun las palabras, como si con garfios me las arrancasen de las entrañas. Esto unas veces más y otras menos, según el Señor quiere, pero lo común es así. No sé si nace de mi falta de fe, aunque en esto mismo procuro avivarla, o de ser esta la voluntad de Dios para humillarme, como que todo es poco para este fin (FDC a FFJG, 16-VII-79, pp. 307-308).

Quizá en tal severidad hacia sí propio resida una de las claves de su éxito, pues es difícil mantener un fuego creador en el alma humana sin los miedos y angustias de la creación. En su caso, sin embargo, se trataba de eliminar el concepto de creación, de producto autogenerado por su talento, en favor de la idea de inspiración, y en tal desplazamiento conceptual a la vez podía albergarse alivio para el miedo y consuelo para la angustia. El providencialismo de esta mentalidad cristiana viene a centrarse, así, en la humilde noción de que el predicador no es sino un canal entre Dios y los fieles, un transmisor, nunca un creador. Eso, en principio, suprime parte de la ansiedad que atenaza al capuchino y le justifica a dejarse arrastrar por sus arrebatos escénicos. Fueron esos asombrosos golpes de efecto los que le otorgaron buena parte de su celebridad, y con ellos conseguía una vibrante sacudida emocional en el auditorio.

Fray Diego no inventaba nada nuevo con esos recursos, porque ya desde el siglo XVII era común que los misioneros recurrieran a lo que Félix Herrero denomina «espectáculos de apoyo», que reforzasen el mensaje de sus sermones mediante elementos retóricos o gestuales perceptibles por los sentidos, y no solo por el entendimiento. En el caso de los jesuitas, Herrero ciñe esos recursos a tres: la exhibición de retratos o representaciones de almas condenadas, el diálogo en el púlpito con una calavera y el uso de un Cristo crucificado que el predicador sostenía $\mathrm{o}$ abrazaba en dolorido coloquio. ${ }^{22}$ Este último fue también el efecto más habitual y

${ }^{22}$ F. Herrero (2003), pp. 336-342. Por su parte, J. Berruezo (1998), p. 82, comentando la obra teórica de Pedro Calatayud, añade la talla del Ecce Homo en las procesiones de penitencia y las bulas de indulgencia, así como la campanilla con que la pareja de predicadores anunciaba su entrada en los pueblos y encabezaba las procesiones, lo cual puede considerarse simplemente como el aparataje mínimo de lo que el célebre jesuita denominaba como «otros instrumentos que se juzgan conducentes para el mayor atractivo y fruto». Los trabajos de Rico Callado citados profundizan, por su parte, sobre el conjunto de técnicas «parateatrales» y su vínculo con la cultura y el arte barrocos, como los ejercicios espirituales y su intento de vívida representación sensorial de escenas penitenciales, el empleo dramático de la voz, la iluminación o la música, la gestualidad, el uso dinámico del 
celebrado de Fray Diego, que haría luego fortuna en su iconografía como Beato: tomaba en sus manos el Santo Cristo que siempre le acompañaba en el púlpito y volviéndolo hacia sí en el trance más intenso de la misión, el acto de contrición, se ponía a hablarle de los pecados del auditorio y de su ingratitud, con sarcasmos, reconvenciones o lamentos apropiados para cada ocasión. Esas frases concluían con grandes gritos, dirigidos ya hacia los fieles, en que les amonestaba por no estar a la altura de la expiación de sus pecados que había sufrido por ellos Cristo. ${ }^{23}$ Este recurso le acompaña desde el comienzo de su oficio, cuando misionaba en Estepona y obtuvo un gran éxito con esa ocurrencia que desde entonces hizo menudear en sus prédicas.

Otro de sus habituales golpes era, en un clímax de indignación hacia la dureza de corazón de los oyentes, abandonar atropelladamente el púlpito sin realizar el acto de contrición, en el que era especialista, ${ }^{24}$ como si la maldad de los pecadores que tenía delante no mereciese misericordia, sino la condenación eterna. Eso provocaba

espacio en que acontecía el sermón, la llamada «predicación a los ojos», figuras retóricas como la hipotiposis y la proposopeya, las procesiones como acto simbólico colectivo, la gradación y dosificación de los elementos a fin de crear una tensión o una sorpresa que coadyuvara al propósito, alusiones o interpelaciones a personas o grupos concretos asistentes al sermón...

${ }^{23}$ Cf. la misión de Baza (FDC a FFJG, 18-VI-79, pp. 273-274). El acto de contrición y demás elementos devocionales de la técnica misionera estaban asociados al Cristo crucificado, es decir, la figura del Dios hecho hombre para redimir con su sufrimiento las culpas de la humanidad. El sacrificio de Cristo era el eje de la predicación y de la devoción «contricionista», como la denomina Rico Callado. El acto de contrición había sido desarrollado en el siglo XVII por el jesuita P. Jerónimo López como un evento diferenciado en la misión, pero con frecuencia se incluía en la estructura ordinaria de los sermones. En línea parecida, Sánchez Blanco destaca que los jesuitas, con Pedro Calatayud a la cabeza, introdujeron en España a principios del XVIII la devoción al Corazón de Jesús, con intención de orientar «la predicación y la piedad popular hacia metáforas contrapuestas a las innovaciones culturales» y buscando «oponer al creciente racionalismo un contrapeso sentimental» (1988), p. 18. Por su parte, los capuchinos insistían en otra devoción también centrada en la penitencia del Redentor: la del Vía Crucis. Cf. Callahan (1989), p. 69.

${ }^{24}$ Así lo relataba el cronista de su misión en Murcia: «En el acto de contrición, y con el crucifijo en las manos, es irresistible. Las acciones expresivas de su cuerpo y rostro; los abrazos con el Señor; aquel levantarlo y mirarlo tiernamente; aquellos coloquios tan dulces, con que desahoga el amor que interiormente le abrasa, no hay con qué compararlos. Ni Antonio enfurecería tanto al pueblo romano contra el que dio muerte al César cuando les manifestó su toga deshecha a puñaladas y manchada con su misma sangre, como el Padre Cádiz hace aborrecer el pecado que fue la causa de la muerte de nuestro Redentor, cuando lo presenta escarpiado en la Cruz que le formaron nuestras culpas. Aquel dulce vida de mi esperanza con que lo estrecha en su pecho, es capaz de ablandar los corazones más empedernidos. Aquellas lágrimas que corren por sus mejillas y las arroja su celo y caridad, liquidan la insensibilidad de los espíritus más obstinados», A. Rovira (1787), pp. 15-16. 
espanto en las gentes, que corrían tras él a suplicarle que regresase y le prometían reformarse. Así aconteció en Estepa:

Yendo ya por la calle para la plaza, y llevando el Crucifijo grande reclinado sobre el pecho y brazo izquierdo, me sentí dar un vuelco el corazón y moverme a no hacer acto de contrición aquella tarde; empezaron los temores de si sería cosa mía y se reiría el pueblo, etc.; pero, acordándome que usted me tiene mandado siga estos movimientos, me resolví a ello, y para más seguridad se lo propuse al Padre Eusebio, y lo aprobó.

En efecto, al concluir la plática, reconvine al pueblo con la desconfianza que me quedaba de si se aprovecharía de lo que acababa de enseñarles, poniéndoles por prueba el poco fruto de la tarde antecedente. Díjeles con mucha serenidad en el modo y fuerza en la expresión que darían lugar a que Dios tomase la mano, como la tomaría, si no trataban de darse por entendidos, que yo me empeñaba en que no sucediese, mas desde entonces levantaba mi mano para que se cumpliese la voluntad de Dios. Pedí al Señor volviese por su causa, y al pueblo dije que no le daba los remedios que para su justificación y salvación propongo en mis sermones, porque [...] [nada] podía ser útil a los que desprecian la palabra de Dios; sí les exhortaba como Cristo, mi Señor, a Judas, que siguiesen en sus designios de ofenderle y aumentar sus culpas, etc., y que en esta inteligencia me retiraba, dejándolos en manos de su mal consejo. Retireme, y nos volvimos a nuestro destino, quedando la plaza llena de gritos, llantos, confusión y otros varios afectos y efectos [...].

De esto resultó conmoverse el pueblo de modo que algunos a voces decían sus culpas, y pedían confesión; se hicieron desde aquella noche, por todas las restantes, muchas procesiones de penitencia; todos los rosarios; el clero por comunidad salió a las diez o más de la noche, rezando el Miserere, cantando saetas, etc. [...] (FDC a FFJG, 31-III-80, pp. 394-395).

A los efectos de valorar, en esta cita y otras varias de las que se van espigando de estas cartas, el sentido del «fruto» obtenido por los sermones, ha de hacerse memoria de la extrema importancia que la técnica misional había conferido al sacramento de la confesión, que de tal modo se convertía en uno de los modos de medir su éxito. ${ }^{25}$ Por tanto, los efectismos escénicos tienen como fin último crear la atmósfera afectiva que provoque el sentimiento de culpa del pecador: la culpa lleva al arrepentimiento y este a la confesión, con la que el alma se pone en suerte de iniciar un cambio de conducta, es decir, una conversión. El acto de contrición

25 «La confesión [...], sin duda, fue el eje esencial sobre el que los misioneros construyeron la devoción. [...] estaba profundamente imbricada en la misión. Los mismos misioneros cifraban su éxito en el número de conversiones o, concretamente, en el de las confesiones generales. La exigencia de esta última tenía como objetivo crear una suerte de "tabla rasa" sobre la que asentar la vida del fiel», F. L. Rico Callado (2002, «Conversión...»), p. 383. 
estaba especialmente dispuesto para desencadenar ese resultado mediante una catarsis colectiva.

Como el P. Cádiz pudo comprobar, en ocasiones la negativa a efectuar el acto de contrición podía extraer los mismos frutos que se pretendían con él. La clave estaba en provocar el miedo y la culpa quebrando la rutina ya convencionalizada de la misión. Es una muestra evidente del valor que adquieren la improvisación y la reacción a los estímulos del auditorio. Ya desde los tiempos de Jerónimo López, más de un siglo antes, los misioneros habían comprendido que la previsibilidad anulaba cualquier efecto de la predicación y que era necesario acudir a la sorpresa, que solo podía venir de un manejo audaz de la técnica y de la confianza en los propios impulsos. ${ }^{26}$ Fray Francisco Javier González incitaba a su discípulo a abandonarse a su inspiración, porque era otra forma de desprenderse del amor propio, y porque la providencia se manifiesta a través de esas pulsiones aparentemente irracionales, pero al tiempo, siguiendo la doctrina de la Iglesia, le imponía el deber de consultarle a él o a otras autoridades la naturaleza de sus arrebatos, para discernir si eran de origen divino o demoniaco.

Tú no hagas empeño por ir aquí o allí a hacer misión; hazla donde te manden con indiferencia; déjate conducir con suavidad de los movimientos que te imprima la voz del Señor, o externa por los que están en su lugar, o interna por inspiración que siempre, si no te arrebata sin dejarte libertad, deberás consultar y sujetar a ajeno juicio, no te precipite celo indiscreto (FFJG a FDC, 26-VI-78, p.127).

Pero el criterio del director es claramente favorable a que se deje arrebatar, incluso si no hay tiempo para consultarlo porque el impulso le sobrevenga en el púlpito:

Te tengo prevenido que en esos casos no te partas de ligero, sentida la moción, humíllate, y levanta el corazón a Dios [...] y, si la moción sigue, y hay a quien comunicársela con confianza, hazlo y obra. Cuando es fuerte, falta tiempo y su ejecución urge, como sucede o puede suceder predicando, obra con ella y no temas, que Dios está contigo (FFJG a FDC, 7-IV-80, p. 400).

El director distingue dos posibilidades: una idea que se presenta con tiempo y se puede consultar, y un arrebato espontáneo que se apodera del predicador sin dejarle libertad, y en el que solo se puede fiar de su criterio (aunque a posteriori consulte lo

\footnotetext{
${ }^{26}$ Escribía López que «conviene usar remedios fuertes aunque parezcan temerarios. Así para curar y domar la rebeldía de los pecadores obstinados conviene salir del paso común de la predicación ordinaria y usada, y buscar nuevos medios, aunque parezcan extravagantes y poco usados. Y esto, aunque la prudencia humana los condene por imprudentes, pues vemos que con semejantes remedios bien aplicados cobran salud los enfermos desahuciados»", citado en F. L. Rico Callado (2003), p. 115 (tomado de la biografía de López por Martín de Lanaja, 1678).
} 
ocurrido). En cuanto a la primera posibilidad, la correspondencia permite ver que muchas veces esas inspiraciones no eran espontáneas, sino un recurso programado. Así lo vemos en la misión de Estepa, en el largo texto ya citado, donde el capuchino declara que la idea le surge yendo de camino al sermón y la consulta con su compañero de viaje, el P. Eusebio. Otro tanto apreciamos en Écija en 1778. Fray Diego escribió con urgencia una carta a su maestro para someterle una idea que le había asaltado para el sermón que tenía que pronunciar ante las autoridades municipales, que estaban sañudamente enconadas en discordias intestinas. Había decidido predicar sobre las obligaciones de un magistrado respecto a Dios, al Rey y al pueblo:

...estando diciendo Misa el día 15, al tiempo de consagrar el cáliz, se me distrajo la imaginación, o se ocurrió al pensamiento, que esta plática la concluyese con arrojar o poner en el suelo de la Sala Capitular el santo Cristo, como entregándoselo, para que viesen lo que hacían.

La noche del mismo día, rezando los Maitines, se ocurrió con más fuerza lo mismo, y el modo de ejecutarlo que fuese (poniéndolo en medio) llamar con alguna expresión eficaz la atención de todos, para recopilar la doctrina de la plática en aquel Dios crucificado, que es el Dios desobedecido, el Rey no atendido, y el pobre del pueblo abandonado, etc.; y terminar así: qué deban VV. SS. hacer con ese Dios así ofendido, con ese Rey desatendido y con ese pobre abandonado, VV. SS. consúltenlo, mientras yo me retiro a la Iglesia o al convento a pedir al Señor les dé luz de lo que han de determinar; y diciendo esto, salirme de la Sala y venirme.

Siguió todo esto después del rezo y durante la visita de altares, en que, todo metido en esto, se puso en el pensamiento y no más esto: ¡Hazlo! ¿No te lo digo yo? En el mismo modo decía el pensamiento lo contrario, fundado en mis justos temores; y se siguió un: ;Yo te asistiré! Sacudía el pensamiento y el propio me satisfizo: Dilo a tu Padre González. Lo despreciaba y se apartaba esto de mí: ¡Hazlo por el amor de Dios! Todo esto era una ocurrencia natural, al modo de los pensamientos inútiles que distraen en la oración; mas conocía yo en estas propuestas un como rendimiento o deshacimiento amoroso en quien lo dijese, cual si alguno lo expresase, al modo que cuando una criatura, o muy necesitada o muy aficionada de una cosa, que ve difícil de conseguir, insta con humilde amorosa instancia a que se la den. No sé explicarme de otro modo (FDC a FFJG, 17-XI-78, pp. 166-167).

En este episodio vemos una compleja elaboración: la idea sobreviene en instantes de devoción o recogimiento, diciendo misa o rezando, lo que sugiere de entrada una inspiración divina; se entabla un diálogo interior entre el impulso y los reparos de su conciencia y su miedo; se somete la decisión al director espiritual, pero con una clara súplica de que este le autorice, pues el modo de presentarle su problema no deja lugar a dudas de que está deseando probar ese arriesgado golpe. González le contesta al día siguiente con máxima urgencia: sea cual sea la procedencia de esa 
inspiración — natural, divina o demoniaca—, «nada tiene de reprensible ni de indecente», pero ha de precaverse con varias exigencias ascéticas ese día, que incluyen mucha oración, rigurosas disciplinas (es decir, mortificar la carne con especial severidad para enaltecer el espíritu y castigar el amor propio) y solo entonces, finalmente:

...dejado todo a Dios, haz lo que piensas; pero de ningún modo poniendo el santo Crucifijo en el suelo, sino, después de lo que digas, [...] déjalo sobre la mesa capitular u otro sitio decente, de modo que los sorprendas, y te retires con espíritu de suavidad y cortesanía (FFJG a FDC, 18-XI-78, p. 169).

Sin embargo, una vez autorizado, Fray Diego llevó mucho más lejos el golpe de efecto que preparaba, dejándose en verdad arrebatar por el ardor de una inspiración. El 1-XII-78, el capuchino escribe una larga carta dando cuenta menuda de lo acontecido en el sermón final de la misión ecijana. La parte más sustanciosa dice así:

Tomé el santo Cristo, les dije se estuviesen sentados, y ¡oh Padre de mi corazón! Irruit in me spiritus irae furoris Domini. Con un furor extraño, como ebrio de ira santa: este es aquel Dios (dije con grito formidable) que sin temor a los poderosos del mundo sabe ahogar a un Faraón, acabar con un Senaquerib, y poner entre las bestias a un Nabuco. Este es aquel Dios, dije por segunda vez con mayor grito, y dando un furioso golpe sobre la mesa con el pie de la cruz, saltó hecha pedazos la imagen del Señor, y cayó por los suelos. Sentilo interiormente, pero siguiendo mi asunto, hasta la cruz dije, etc., y proseguí tres o cuatro minutos con aquel ardor; y, templado algo, puse la cruz sobre la mesa, y dando golpes recios con ella tendida, que aquel así despedazado y muerto sería el Juez ante quien comparecerían, que él era el oprimido en Usía, el perseguido en el pobre, el abandonado en el huérfano, y el enfermo olvidado, el perseguido en el inocente. ¡Ese es, ése es, señor! Véalo V. S.; consulte ya lo que ha de ser con ese pobre; piénselo despacio, mientras yo voy a pedirle en la oración dé a V. S. la luz que necesita para su acertada resolución. Me salí de la sala con alguna prisa, y con paso acelerado me vine al convento, me fui al coro, y postrado en tierra estaría un cuarto de hora, pidiendo al Señor el feliz éxito en todo (FDC a FFJG, 1-XII-78, p. 173).

El éxito fue, según dice, formidable y los aterrorizados miembros del cabildo accedieron a todas las peticiones del predicador, se encargaron de recomponer la cruz rota, que les fue donada luego por Fray Diego para que presidiera las reuniones de la corporación. Los días siguientes continuó predicando en Málaga y le costaba desprenderse de esa ira divina que tan buen resultado le había reportado:

El interior anda algo fácil en tener a Dios presente, y sensible frecuentemente para con los prójimos, bien que con unos furores tan fuertes para predicar amenazas, castigos, etc., que me cuesta trabajo sujetarme en los púlpitos, porque se siguen 
algunos desórdenes en el pueblo, que me son muy sensibles (FDC a FFJG, 29-XII78).

El P. González le respaldó en esos accesos furiosos, que considera que solo pueden provenir de Dios, liberándole de toda carga de culpa. Le reprocha que tenga miedos, que dude, que busque la aprobación humana para sus actos en el púlpito, que no son sino una inspiración divina. En suma, exacerba la espontánea tendencia del capuchino a dejarse arrastrar por una oratoria airada y emocional: « $i$ Mal dicho y mal hecho, lo que hiciste y dijiste! Nunca, después que obres, como en esta ocasión, con consejo, con inspiración, con previa oración y pura intención, des lugar a reflexión alguna, aunque te combatan millones de ellas» (FFJG a FDC, 9-I-79, p. 182).

Los recursos del predicador no siempre son tan espectaculares, a veces son argucias argumentativas. Así, en la misión de Málaga tuvo otro golpe, pero de una naturaleza bien diferente a los que se han comentado hasta ahora:

...el día de la comunión general [...] haciendo cargos al pueblo del corto fruto que se notaba, me ocurrió, habiéndolo pensado antes, el decir los pecados cometidos aquel día. Acordeme de ello en el sermón, quise desecharlo, pero me pareció sería bien el decirlo, y así dije esta proposición: ¿Queréis ver el fruto de esta Misión? Pues inferidlo de esto, que quizá no lo creeréis: «Desde las doce de la noche hasta ahora se han cometido en Málaga veinte y dos mil pecados mortales, y entre ellos tres o cuatro deformes, que por no escandalizaros no los digo». (Creo que es seguro, y aun corto este cómputo, porque seguramente pasan de 50000 las personas de esta ciudad.) Esta expresión conocí entonces, y he visto después ha sido extraordinaria la fuerza que tuvo en toda clase de gentes.

Al concluir la plática, exclamé a Dios con el exurge, Domine, judica causam tuam, y que yo levantaba mi mano, para que, si quería castigarnos, lo hiciese. Volvime al pueblo con ardor de espíritu, y con grito terrible les dije: y vosotros id, et implete mensuram patrum vestrorum, para que venga el castigo. Tomé el lienzo de la Divina Pastora, y con aceleración bastante me bajé del púlpito. Este serio conjunto de expresiones y acciones movió tanto, que toda, toda la ciudad se puso en movimiento (FDC a FFJG, 12-III-79, pp. 200-201).

Aunque el gesto final de coger la imagen de la Virgen y abandonar el lugar con atropello pertenece al tipo de acciones teatrales que ya hemos visto, la duda que plantea reside en un punto de dialéctica, no de retórica ni gestualidad: reducir a estadística los pecados de los oyentes. El argumento lógico, sin embargo, en todo acto de oratoria de este tipo, deviene inmediatamente en gesto y golpe emocional. Como de costumbre, le asaltaron remordimientos sobre si había hecho bien. Su escrúpulo por el cómputo de pecados de los malagueños era si no podía considerarse una mentira, es decir, un puro artificio retórico, con la carga peyorativa que tales artimañas arrastraba en la tradición moralista. Este es un punto central en 
la reflexión sobre los sermones de Fray Diego, el de diferenciar la mentira, la triquiñuela teatral, de la genuina inspiración divina. Las instrucciones de su maestro incidirán en esta distinción:

Si para confiadamente decir el número de pecados cometidos, suponiendo entre ellos algunos de mayor maldad y escándalo, si los había, obraste como orador, usando de esa pura conjetura con oportunidad para moverlos a penitencia, obraste mal; porque, aunque sea racional el cómputo, considerada la multitud de vecindario, y por su mucha relajación dominante puede ser cierto, ¿te constaba que lo era? ¿Podías sin exponerte a mentir decirlo como si te constara? ¿Puede la mentira, que siempre es mala, servir de algo en la cátedra de la verdad? No apruebo esos medios de mover.

Si para decirlos con tanta puntualidad, y afirmarlo como cierto, te sentiste inspirado o movido, y te pareció que convendría, aún hay que temer, porque no siempre inspira el Señor, sino nuestro propio dictamen y errado juicio, o el enemigo que calienta el celo para que sea indiscreto. A semejantes pensamientos tuyos e inspiraciones equívocas, nunca aprobaré que des oídos, ni obres según ellos [...] porque [...] ¿qué filos le puede dar [a la palabra de Dios] la invención, la exageración y cuantos tropos y figuras le quiera vestir la humana elocuencia? Dáselos el que la anuncia con candor, con sencillez, con reverencia, con humilde conocimiento de que no es digno de pronunciarla, y con pavoroso respeto [...]. Quien así prevenido y dejado todo al espíritu que le agita, sin perder de vista la sola gloria de Dios en el ministerio, si allí, allí mismo, cuando lo ejercita, prorrumpe en alguna expresión terrible o fausta, amenazando, prometiendo, mandando, suplicando, previniendo lo que será, manifestando lo que es, no la contenga; pero tampoco la exprese, cuando antes se le proponga que la diga, sin primero examinar muy seriamente a los pies de Jesucristo, o de quien esté en su lugar, como Prelado, Director o justo amigo, si convendrá decirla (FFJG a FDC, 20-III-79, pp. 211-212).

Aquí se arma toda una teoría para manejar la oratoria sagrada que, paradójicamente, es una antirretórica o una retórica vergonzante, porque pasa en apariencia por despreciar los recursos oratorios en la predicación de la palabra divina, para sin embargo entregarse de lleno a ellos una vez han sido cribados - a través de la autoridad del director- mediante los filtros del discernimiento. El P. González condena los golpes de efecto de Fray Diego si los hace como orador, es decir, si son un artificio verbal; eso, además de ser una mentira, sería un exceso del amor propio. Para ser lícitos, esos recursos tienen que venir de fuera del individuo, esto es, tienen que ser inspirados. Pero en las inspiraciones aún hay que distinguir entre las que vienen de uno mismo, que son engaños del ego ensoberbecido; las que vienen del Enemigo; y las que vienen de Dios, únicas aceptables. Tal discernimiento se consigue por la oración, el consejo de las autoridades espirituales — que poseen eventualmente los recursos coercitivos para imponerlo- y la determinación del 
fruto favorable conseguido, ya que si el sermón hace la obra de Dios ha de ser porque provenga de Él.

Si analizamos estas reglas, vemos que la diferencia entre la oratoria sagrada y la profana, entre la verdad y la mentira, la inspiración y el artificio, no se sitúa en el plano formal retórico. La piedra de toque no es lo que se dice, ni cómo se dice, ni el color oratorio escogido, sino el origen del discurso, su procedencia providencial o meramente humana, y aquí la única posibilidad de discernir proviene de la fe de quienes producen la pieza retórica y de quienes la reciben. Casi la totalidad de la reflexión de Fray Diego acerca de su técnica consiste en diferenciar el origen de esa inspiración que le arrebata en el púlpito y le señala el modo de conmover las mentes de sus oyentes para aterrorizarles o hacerles arrepentirse. Ese miedo siempre acompaña los actos del capuchino, que sin embargo pocas veces deja de responder a la llamada de su inspiración:

[En Granada] prediqué desde lo alto de una tapia. La especie fue que, despidiéndome de todos, manifestándoles el amor que les tenía, les dije, que cuando alguno se viese en el Tribunal de Jesucristo mi Señor apretado de los cargos, me llamase, que yo abogaría por él desde acá, y representaría la devoción con que había concurrido a oír la palabra de Dios, etc. Esto ocurrió allí con no pequeña fuerza y devoción; lo resistí una vez, y volvió otra con igual fuerza, y a la segunda o tercera ocasión lo dije: conocí gran moción en el pueblo; pero no sé más de sus efectos. Estos arrojos míos me dan no poco que pensar después; pero desecho toda reflexión, dejándome a Dios, para que haga lo que guste de mí. Pero ¿y si no es de Dios? Estos son mis temores, y lo que me tiene en una prensa terrible (FDC a FFJG, 16-V-79, pp. 263-264).

De las frases que cita el P. Cádiz en el pasaje anterior, algunas fueron denunciadas a la Inquisición. Cosas como esa justifican los temores de los que habla, que no son sin embargo temores doctrinales tanto como políticos. Es decir, no le angustia el fondo, sino la oportunidad: cuando dice que sus arrojos le dan lugar a inquietudes y reflexiones, a lo que se refiere con frecuencia es al miedo a haber hablado de más y suscitar el desagrado del poder. Uno de los contenidos más habituales de estas cartas se consagra a medir hasta qué punto puede el predicador defender las ideas ultramontanas que ambos corresponsales comparten sin incurrir en escándalo y en conflictos con el gobierno y las autoridades eclesiásticas menos afines. Si bien los dos frailes están convencidos de que hay que combatir la perniciosa ilustración del siglo que ellos llaman tenebroso, y no ilustrado, son asimismo conscientes de que una batalla declarada e imprudente contra el poder, además de resultar escandalosa, acabaría por alejar a Fray Diego de los púlpitos y, por tanto, le impediría hacer la obra de Dios.

Esos temores no eran vanos, como ya se vio por las frecuentes denuncias al Consejo de Castilla, la Inquisición y los ordinarios menos predispuestos al exceso de celo de los regulares. Fray Francisco Javier González le pedía prudencia, pero al 
tiempo le erradicaba todo sentimiento de culpa y miedo a la persecución: de hecho, le insistía en que su destino era ser perseguido y atacado, y que su obligación y gloria consistían en resistirlo como lo había hecho Jesucristo. Es un difícil equilibrio entre transmitir un mensaje sedicioso contra la autoridad y a la vez predicar y practicar la obediencia ante ella. Frente a sus temores y dudas, el director asienta el criterio de inspiración como el que discierne lo correcto de lo incorrecto:

No te aprobaré que un indiscreto celo te precipite (confundiéndolo con el santo y apostólico) en invectivas contra la potestad pública, que sabes tiene a Dios o a la divina Providencia por origen; que declames contra los ministros y consejo; [...] que te arrojes a proposiciones y promesas que sean proféticas en la apariencia, o temerarias en la común estimación de los que las oyen, o demasiadamente vagas y extrañas. [...]

Pero si quiere [Dios], si te inspira con suave violencia, si pone en tus labios sin prevención de tu estudio, reflexión y propio querer esta, aquella u otra proposición, amenaza, promesa, desafío, sentencia, imperio, alienta tu fe, esfuerza tu confianza, habla con ardor santo, y di lo que quieras, que tibi dixi Dominus, dice el que a nombre de Dios habla; y el que habla así ¿qué tiene que temer? ¿Qué puede el mundo, qué puede el infierno, qué sus visibles ministros contra el omnipotente sermón que inspira el Omnipotente? (FFJG a FDC, 28-VI-79, pp. 282-283).

Aquí resulta que la inspiración irreflexiva es prueba de verdad y apuesta de martirio, pero ha de evitar este riesgo en tanto que el acto peligroso proceda «de tu estudio, reflexión y propio querer». La sedición solo es admisible como acto inconsciente inspirado por Dios, no como algo buscado. La línea entre ambos conceptos es tan frágil como se puede imaginar, hasta el punto de tornar el razonamiento bastante sofístico. Y esto conduce a una conclusión, en la que se resume este modo de predicar, y que aleja la posibilidad de un análisis meramente racional de la técnica oratoria y los contenidos pastorales de estos encendidos sermones:

¿Qué importa que todo el mundo y todo el infierno se conjure contra Fr. Diego José de Cádiz y le contradiga, acuse, delate, y aun por días prevalezca? ¿A quién sirve Fr. Diego? ¿Quién lo ha mandado a predicar? ¿Cuál es el fin de su Misión? Si es, como es (bendito sea Dios) su sola gloria la salvación de los prójimos, la extirpación de los vicios, la conservación de la fe, de la religión y de la piedad, postrando y exterminando de nuestro católico Reino el maldito espíritu del libertinaje, ¿qué tiene que temer? ¿Qué? No, hijo de mi alma, pelea con esfuerzo más que de hombre. Dios está, no a tu lado, no sobre ti, sino en ti mismo, en tu corazón, en tus labios. Él te inspira, Él te ilustra, Él te enseña su voluntad y Él por ti predica. Nada, nada, nada, sino la nada misma es tuyo. Nada puedes, nada sabes, nada harías dejado a ti; y por tanto, los aplausos, las estimaciones, los excesos de honor que rinden los pueblos, los auditorios, las personas visibles, no son a ti, sino al que se sirve de ti como de instrumento para que en tu improporción resalte más 
visible su omnipotente virtud (FFJG a FDC, 28-VI-79, pp. 286-287).

Este providencialismo, en pura lógica irracionalista, conduce derechamente a pasar de las inspiraciones divinas en el interior del predicador, a las manifestaciones directas de la mano de Dios, es decir, a los prodigios y milagros que sirven como marca sensible y objetiva de que la Providencia respalda al orador sagrado en su misión. A lo largo del epistolario, y en toda la tradición hagiográfica y popular que rodeó a Fray Diego en vida y tras su muerte, se ronda lo milagroso. Se acumulan anécdotas que las gentes o los protagonistas creen milagros acontecidos en medio de las tareas cotidianas del misionero, siguiendo una inconmovible convicción de que la presencia de Dios en la realidad se manifiesta a cada rato mediante la subversión de las leyes naturales. Ahora bien, los milagros están vinculados a la santidad y declararlos es una potestad exclusiva de las máximas autoridades eclesiásticas, que preservan celosamente tal monopolio. De ahí que aseverar que en los sermones de Fray Diego, o por causa de ellos, acontezcan milagros es un paso que él y su director se cuidan mucho de dar. No obstante, en todo momento lo tienen presente, porque son conscientes de que, sin milagros, no hay certeza de que un santo varón sea el Elegido para ejecutar la obra divina. En las cartas de ambos religiosos, aunque nunca se afirmen como tales, es obvio que ansían prodigios y que están convencidos de que se producen:

Las ansias de las gentes [de Andújar] por la Misión puede usted inferirlas de que algunos estuvieron dos o tres días antes esperando a muy larga distancia hasta las doce y dos de la noche, en medio de los campos, con el escaso abrigo de algún fuego. Se dio principio a la Misión el día nueve; la predicación fue suave, eficaz y no muy penosa al interior: el fruto parece haber sido considerable en el remedio de algunos puntos graves, como el juego, pleitos y enemistades. En esta sucedió un caso que se cree tuvo algo de sobrenatural. En ocasión que estaba yo predicando el sermón del amor a los enemigos en la plaza, se hallaban unos trabajadores arando en el campo, como un cuarto de legua distante de la ciudad a orillas del Guadalquivir, y en este sitio, donde hacía mucho ruido el agua, oyeron con claridad y distintamente cuanto yo decía, de suerte que pararon las yuntas y atendieron al sermón. Luego que entendieron el asunto, avisaron a otro que estaba en el cortijo, exhortándole viniese al pueblo a oír la plática. Oyó él también lo que yo hablaba, y vino a prisa, de modo que llegó a la mitad del sermón, el que, concluido, fue a reconciliarse con cierta familia con quien estaba enemistado (FDC a FFJG, 2-I-82, pp. 546-547).

En suma, el milagro es el grado máximo, el corolario inevitable, de esa inspiración que convierte al predicador sagrado en un médium de la palabra divina, dejándose arrebatar por una fuerza interior de origen providencial. Pero sin embargo se trata de algo «que se cree tuvo algo de sobrenatural», que se trata como tal, tiene efectos como tal, pero nunca se declara como tal. 


\section{Una vieja nueva retórica}

Resumamos. Las notas que emplea Rico Callado para caracterizar el conjunto de la predicación misional, hasta donde admite ser sistematizada, se centran en un punto: "se puede afirmar que una característica esencial del "método" misional consistió en el empleo de técnicas como la improvisación, así como en una continua transformación o "perfeccionamiento" de la forma de persuadir que buscaría la máxima repercusión de un mensaje íntimamente ligado a las circunstancias». ${ }^{27}$ Todo gira, pues, en torno a la habilidad del predicador de acomodarse a cada público y ocasión, mejorando sobre la marcha. Sus métodos de adaptación, sin embargo, nacen de una estética barroca cuya clave consiste en sorprender, captar la atención e incluso pasmar al auditorio como medio de enganchar con él. El epistolario analizado manifiesta hasta qué punto esa improvisación y esa técnica teatralizada son objeto de cavilación, tanto previa como posterior, corroborando que «la persuasión misional, pese a su carácter improvisado, era producto de una larga reflexión y se caracterizaba por su sistematismo». ${ }^{28}$

La cuestión debatida más arduamente en las cartas, sin embargo, no son los modos de dicha improvisación, sino muy en particular su control y legitimación. Dicho con término exacto: la cuestión radica en su discernimiento espiritual, fuente de los miedos y obsesiones del predicador carismático y de su no menos carismático director de conciencia. La angustia de ambos experimentados oradores no atañe a detalles técnicos, a la elección de los temas, al orden y estructura de los discursos, a los juegos retóricos, los ejemplos escogidos, los trucos del tahúr ni los embelecos del ilusionista. No es esta una correspondencia - un pensamiento- de embaucadores ni de peritos en el oficio de sermonear, sino la obsesiva busca del corazón esencial del acto de la predicación para dos sinceros creyentes en el carisma que conlleva: discernir la verdad en cada impulso, y esa verdad para ellos, cristianos providencialistas, consiste en diferenciar los impulsos enviados por Dios de aquellos que nacen de la vanidad, del ego o del Enemigo.

En equivalencia con ese providencialismo que anula el control del individuo sobre sus propias obras, dejándolo todo al cuidado de Dios, el predicador capuchino y su director mínimo promueven un estilo de predicación que se basa en el atento examen de la psicología de las masas y en el abandono al instinto, aunque al instinto se le llame inspiración o carisma. Frente al artificio retórico y al gerundianismo, esta oratoria se asienta sobre los impulsos interiores, aunque luego estos sean discernidos, elaborados e interpretados según los sabios y prudentes dictados de un teólogo. Para guardar mejor tal carisma, el predicador ha de abandonarse, anular la reflexión racional y suprimir su voluntad, como si fuese un

${ }^{27}$ F. L. Rico Callado (2002, «Conversión...»), p. 366.
${ }^{28}$ F. L. Rico Callado (2002, «Conversión...»), p. 375. 
simple médium. Así maneja el P. González las quejas de Fray Diego sobre su aridez en el púlpito: «También quiero que prediques con resolución, dejado a Dios, y sin reflexión alguna de si estoy amargo o dulce, si hay frutos o no, si es por mi causa, etc. Déjate, vacíate, ciégate...» (FFJG a FDC, 10-III-81, p. 489).

¡Déjate, vacíate, ciégate! Una predicación de tal naturaleza pretende basarse en la verdad y no en la mentira, entendiendo que la oratoria ha sido peyorativamente asociada, desde los remotos sofistas atenienses, con la falsedad y el artificio de las palabras. Es una verdad religiosa, claro está, con la que se puede o no estar de acuerdo, pero no cabe negar el propósito de subirse al púlpito poniendo los ardides de las artes retóricas al servicio de la sinceridad y efectividad del mensaje. En cierta ocasión Fray Diego escribió a su director una sentencia que resume esta búsqueda de una autenticidad psicológica: «no olvido la sentencia que escribí a usted, cuando me sentía movido a decirle: no debía subir al púlpito el que no baja movido de lo que en él ha predicado» (FDC a FFJG, 9-XI-79, p. 367). Era la balanza que distinguía el buen sermón del malo. No está lejos de las modernas teorías de la oratoria, en parte construidas contra las retóricas formalistas, como las de Capmany en su Filosofia de la elocuencia de 1777, donde aconsejaba para ser elocuente practicar la pureza moral, pues la verdad está por encima de cualquier primor del arte o del lenguaje: "para ser elocuente no basta hablar como orador, es menester pensar como filósofo» (2002, p. 41), «lo verdadero, de cualquier modo que se presente, siempre es estimable» (p. 74). En ese sentido, se trata de una oratoria sacra limpia de los excesos barrocos y formalistas de los Fray Gerundios que habían dominado el púlpito en épocas anteriores.

Estas actitudes no son tan distantes a las que los ilustrados proponían para renovar la oratoria del siglo a fin de ponerla a la altura de un tiempo en que esperaban que el arte de mover a las gentes recobrase un protagonismo perdido hacía mucho. Siguiendo la clásica oposición entre una retórica basada en el Verbum (palabra divina) y el verbum (artificio humano), Rico Callado sostiene que la reforma de la predicación, que combatía los excesos barroquizantes en pro de un mayor «rigor dogmático y moral», se sostiene en el XVIII en términos que reproducen los que ya se habían defendido en los tratados de la centuria precedente, hasta concluir que «los caracteres esenciales de la reforma de la predicación en el Setecientos carecieron, en gran medida, de originalidad» ${ }^{29}$ Con tal reforma se refiere principalmente, como acostumbra a hacerse desde estudios como los de Joël Saugnieux, al tipo de selectos sermones promovidos por la élite religiosa imbuida de esas ideas que en la España del XVIII se califican como jansenistas. ${ }^{30}$ Aunque

\footnotetext{
${ }^{29}$ F. L. Rico Callado (2000), pp. 311-312.

${ }^{30}$ «Dans la seconde moitié du XVIII ${ }^{\mathrm{e}}$ siècle a lieu en Espagne un mouvement de renouveau de la prédication à cette volonté de réforme de la piété et d'intériorisation du sentiment religieux qui caractérise ce qu'on a appelé le jansénisme espagnol», M. Blanco (1988), p. 153. Blanco destaca la proximidad de ese movimiento a la paralela campaña neoclásica para
} 
los misioneros populares representan un mundo distinto, su planteamiento teórico no estaba tan alejado de la predicación jansenista, en la que «importa mucho más la santidad del predicador que el dominio de la retórica» y se pretende «imponer la sencillez del discurso que, en su opinión, estaba ligada a la transmisión del Verbo divino». ${ }^{31}$ Coincidiendo en dar el papel preponderante en los sermones a la corrección de costumbres, los reformistas de la predicación en el XVIII se alejan, sin embargo, de los predicadores misionales en el rechazo a prácticas que consideran supersticiosas, al recurso a milagros, santos y devociones de la religiosidad popular, junto con el providencialismo taumatúrgico y el culto externo, así como el rechazo al uso abusivo del miedo a la muerte y al fuego eterno como prueba de convicción para conseguir la conversión de los oyentes; esos elementos seguían siendo esenciales en las misiones y eran evitados por los predicadores cultos, que en cualquier caso limitaban su empleo al segmento más iletrado del pueblo. ${ }^{32}$ Ha de tenerse en cuenta, a estos efectos, que la predicación elitista del XVIII pretendía no solo una reforma de la oratoria, sino un nuevo tipo de espiritualidad, mientras que los misioneros lo que buscaban era el medio más directo y eficaz de reforzar y restaurar la espiritualidad tradicional. A partir de ahí, sin embargo, las oposiciones teóricas entre los estilos y modelos de predicación, son harto más fluidas de lo que parecen sobre el papel.

Y, por otro lado, en una época en que se percibía un gran combate entre las ideas antiguas y las modernas, $y$ en la que se daba por descontado que ese combate no podía ya quedarse al margen de la opinión pública y del debate social, iba a ser necesario que la retórica recuperase su autenticidad, renovase sus recursos para conquistar y movilizar a una emergente ciudadanía. Por las mismas fechas en que Fray Diego escribía sus cartas a su director, en 1777, Antonio de Capmany publicaba su Filosofía de la elocuencia, en la que trataba de fijar «filosóficamente», es decir, rehuyendo el método y las rigideces de los manuales de retórica tradicionales, los principios de la oratoria y el buen estilo que devolviesen el arte de la palabra pública a su genuino papel. Capmany también insiste de continuo en que no existe mayor eficacia en un discurso que la que otorga la verdad de su contenido,

«limpiar» la poesía y la prosa literarias de los ornamentos y conceptismos del Barroco y acumula testimonios al respecto de Mayans e Isla, subrayando su cercanía a las ideas de los oradores jansenistas franceses del XVII, aunque sean mucho menos coherentes y radicales que estos (pp. 157-158).

31 F. L. Rico Callado (2000), pp. 313. «Le prédicateur ne doit pas s'adresser primordialement a l'intelligence ni à l'imagination; son coeur enflammé de charité doit faire parvenir la parole de Dieu au coeur des auditeurs. Même s'ils croient demander qu'on les amuse avec de beaux discours, les fidèles désirent la parole divine dans sa simplicité», $\mathrm{M}$. Blanco (1988), p. 155, parafraseando a Mayans.

${ }^{32}$ Véase sobre el rechazo a los milagros y a la «pastoral del miedo» en los reformadores de la predicación jesuita la excelente exposición de Rico Callado (2000), pp. 331-339. 
y en huir de la frialdad del estudio, dando una gran importancia a la fuerza psicológica que presta la sinceridad y la imaginación al orador. «La imaginación, siempre que no se abusa de ella, es una de las bases del gusto (...) porque la fría razón, cuando no va acompañada, apaga el gusto en un escrito ameno y en el alma del oyente». ${ }^{33}$

Las ideas oratorias de Capmany son otra muestra de la nueva dirección impresa a la elocuencia pública por los ilustrados, y antecedente del gran auge que la era de las revoluciones liberales volverá a otorgar a la retórica política en una sociedad abierta y participativa. Del lado contrario a las ideas del siglo, los predicadores reaccionarios también se aprestaban a usar la oratoria sacra en el gran combate contra la modernidad, pero igualmente Fray Diego de Cádiz define un arte de la palabra basado en la emoción, la imaginación y la verdad, en escuchar los impulsos del alma y en dejar que el estudio se limite a pulir el instinto. Salvando la distancia entre la actitud filosófica, es decir, racionalista, de Capmany, y el providencialismo irracional y aun fanático del capuchino, ambos muestran que la retórica, sacra o profana, estaba de nuevo en el centro de la vida pública.

\section{Obras citadas}

Aguilar PIÑAL, Francisco: «Predicación y mentalidad popular en la Andalucía del siglo XVIII», en Carlos Alvarez y Santaló, María Jesús Buxó i Rey y Salvador Rodríguez Becerra (coords.), La religiosidad popular, Barcelona, Anthropos, 1989, t. II, pp. 57-71.

AUSEJO, Serafín de: Reseña bibliográfica de las obras impresas del Beato Diego José de Cádiz (1743-1801), Madrid, Instituto Nacional del Libro Español, 1947.

BLANCO, Mercedes: «Ambiguïtés d'une réforme. La critique de la prédication conceptiste au XVIIIe siécle», Mélanges de la Casa de Velázquez, t. XXIV (1988), pp. 153-175.

BURRIEZA SÁNCHEZ, Javier: «Ciudades, misiones y misioneros jesuitas en la España del siglo XVIII», Investigaciones históricas: Época moderna y contemporánea, $\mathrm{n}^{\mathrm{0}} 18$ (1998), pp. 75-108.

Caballero Venzalá, Manuel: «El Beato Fray Diego José de Cádiz: sus cartas inéditas al Cabildo Catedral de Jaén y su presencia en la imprenta del Santo

\footnotetext{
${ }^{33}$ A. Capmany (2002), p. 46. «El orador no debe atormentarse disputando con cada palabra y con cada sílaba: trabajo y delicadeza infructuosa que no puede dejar de apagar el calor del sentimiento y de la imaginación» (p. 64). En esa línea, define la oratoria como «el lenguaje del sentimiento» (p. 128) y afirma que las figuras retóricas no proceden del arte, sino de la misma naturaleza, que «las dicta (...) en el tumulto de las pasiones» (p. 111).
} 
Reino», en Varia Bibliographica. Homenaje a José Simón Díaz, Zaragoza, Kassel Edition Reichenberger,1988, pp. 127-135.

CALlaHAN, William J.: Iglesia, poder y sociedad en España, 1750-1874, Madrid, Nerea, 1989.

CAPMANY y MONTPAlaU, Antonio de: Filosofía de la elocuencia (1777), Ed. de José Juan Berbel Rodríguez, Almería, Universidad, 2002.

Domínguez ORTIZ, Antonio: Las clases privilegiadas en la España del Antiguo Régimen, Madrid, Istmo, 1973.

-----: «Aspectos sociales de la vida eclesiástica en los siglos XVII y XVIII», en Antonio Mestre Sanchís (dir.), Historia de la Iglesia en España. IV. La Iglesia en la España de los siglos XVII y XVIII, Madrid, BAC, 1979, pp. 572.

DURÁN LÓPEZ, Fernando: «Respuesta de Fray Diego José de Cádiz a un regidor de una de las ciudades de España en torno a la ilicitud de las comedias», Draco. Revista de Literatura Española, no 3-4 (1991-1992), pp. 207-251.

-----: «Fray Diego José de Cádiz contra el teatro», en Alberto Romero Ferrer, Fernando Durán López y Yolanda Vallejo Márquez (eds.), VI Encuentro de la Ilustración al Romanticismo: Juego, Fiesta y Transgresión 1750-1850 (Cádiz 16, 17 y 18 de Octubre de 1991), Cádiz, Universidad, 1995, pp. 501512.

-----: Tres autobiografias religiosas del siglo XVIII. Sor Gertrudis Pérez Muñoz, Fray Diego José de Cádiz, José Higueras, Universidad, Cádiz, 2003.

-----: Un cielo abreviado. Introducción crítica a una historia de la autobiografía religiosa en España, Fundación Universitaria Española, Madrid, 2007.

GÓMEZ NAVARRO, Soledad: «Con la palabra y los gestos: las misiones populares como instrumento de cristianización y recristianización en la España Moderna», Ámbitos. Revista de estudios de ciencias sociales y humanidades, $\mathrm{n}^{\circ} 19$ (2008), pp. 11-23.

Herrero SALGADO, Félix: La oratoria sagrada española de los siglos XVI y XVII, Madrid, Fundación Universitaria Española, 1996-2004 (4 vols.).

-----: «Las misiones populares de los jesuitas en el siglo XVII», en Javier Vergara Ciordia (coord.), Estudios sobre la Compañía de Jesús: los jesuitas y su influencia en la cultura moderna (siglos XVI-XVIII), Madrid, UNED, 2003, pp. 313-360.

LÓPEZ-CORDÓN CORTEZO, María Victoria: «Predicación e inducción política en el siglo XVIII: Fray Diego José de Cádiz», Hispania, no 138 (1978), pp. 71119.

MATEO AVILÉS, Elías de: «Las santas misiones en la diócesis de Málaga durante el siglo XIX», en Carlos Álvarez y Santaló, María Jesús Buxó i Rey y Salvador Rodríguez Becerra (coords.), La religiosidad popular, Barcelona, Anthropos, 1989, t. II, pp. 174-189. 
Melgares RaYA, José: «Fray Diego José de Cádiz (1743-1801)», Boletín del Instituto de Estudios Gienenses, $\mathrm{n}^{\mathrm{o}} 153$ (1995), pp. 1031-1039.

MORÁN, Manuel y José ANDRÉS-GALLEGO: «El predicador», en Rosario Villari (ed.), El hombre barroco, Madrid, Alianza,1992, pp. 162-200.

OTT, Olivier: «Prédication et violence en Espagne à la fin du XVIIIe siècle: le vitupère des "philosophes" chez Fray Diego de Cádiz (1786-1797)», Imprevue, I (1981), pp. 41-65.

PÉREZ ORTEGA, Manuel Urbano: «Misión giennense de Fray Diego José de Cádiz: la supresión del teatro», Demófilo. Revista de cultura tradicional de Andalucia , no 33-34 (2000), pp. 127-142.

Rico CAllado, Francisco Luis: «La reforma de la predicación en la orden ignaciana. El nuevo predicador instruido (1740) de Antonio Codorniu», Revista de historia moderna, $\mathrm{n}^{\circ} 18$ (2000), pp. 311-340.

-----: «Espectáculo y religión en la España del Barroco: las misiones interiores», Chronica nova, $\mathrm{n}^{\circ} 29$ (2002), pp. 315-339.

-----: «Conversión y persuasión en el Barroco: propuestas para el estudio de las misiones interiores en la España postridentina», Studia historica. Historia moderna, $\mathrm{n}^{\circ} 24$ (2002), pp. 363-386.

-----: Las misiones interiores en la España de los siglos XVII-XVIII, Biblioteca Virtual Miguel de Cervantes, Alicante, 2002 (tesis doctoral).

-----: «Las misiones interiores en España (1650-1739): una aproximación a la comunicación en el Barroco», Revista de Historia Moderna, no 21 (2003), pp. 189-210 (cito por edición electrónica con paginación distinta).

-----: «Las misiones interiores en la España postridentina», Hispania Sacra, 55 (2003), pp. 109-129.

ROVIRA Y GÁlVEZ, Alfonso: Relación de lo ocurrido en la Santa Misión que desde el día 11 de abril de este presente año de 1787, hasta el 22 del mismo, hizo en esta ciudad de Murcia el M. R. P. Fr. Diego José de Cádiz... Tercera impresión, Sevilla, Imprenta de Vázquez, Hidalgo y Cía., [1787].

RUIZ SÁNCHEZ, José Leonardo: «Cien años de propaganda católica: las misiones parroquiales en la archidiócesis Hispalense (1848-1952)», Hispania sacra, t. 50, no 101 (1998), pp. 275-326.

SÁNCHEZ-BLANCO, Francisco: «La situación espiritual en España hacia mediados del siglo XVIII vista por Pedro Calatayud: lo que un jesuita predicaba antes de la expulsión», Archivo hispalense, 71, nº 217 (1988), pp. 15-33.

VAlencina, Fr. Ambrosio de (ed.): El director perfecto y el dirigido santo. Correspondencia epistolar del B. Diego José de Cádiz con el V. P. Maestro Francisco Javier González y viceversa. Sacada a luz y anotada por el M. $R$. P. Fray Ambrosio de Valencina, ex provincial de los PP. Capuchinos de Andalucía. Con las debidas licencias (cuarta edición), Sevilla, Imprenta de la Divina Pastora, 1924. Primera edición de 1900. 
Valencina, Fray Diego de (ed.): Cartas de conciencia que el B. Diego J. de Cádiz dirigió a su director espiritual D. Juan José Alcover e Higueras, Dignidad de Abad de la Colegiata del Salvador de Granada, anotadas por el M. R. P. Diego de Valencina, Definidor de la Provincia de Capuchinos de Andalucía y Vicepostulador de la Causa de Canonización del mismo Beato. Con un prólogo-censura del M. Itre. Sr. Dr. D. Juan F. Muñoz Pabón, Lectoral de la Santa Iglesia Metropolitana y Patriarcal de Sevilla, Sevilla, Tipografía de la Divina Pastora, 1904.

ZARAGOZA PASCUAL, Ernest: «Cartes inèdites del beat Diego José de Cádiz al pare Jaume de Puigcerdà OFM Cap (1790-1801)», Analecta sacra tarraconensia, vol. 76 (2003), pp. 213-256. 